\title{
Bax- $\alpha$ promotes apoptosis induced by cancer chemotherapy and accelerates the activation of caspase 3-like cysteine proteases in p53 double mutant B lymphoma Namalwa cells
}

\author{
Estelle Schmitt ${ }^{1}$, Alain Steyaert ${ }^{1}$, Guido Cimoli ${ }^{1}$ and \\ Richard Bertrand ${ }^{1,2}$ \\ ${ }^{1}$ Hospital Research Center of University of Montreal, Montreal Cancer Institute \\ Montreal (Que) H2L 2M1 Canada \\ 2 corresponding author: CHUM, Notre-Dame Pavilion, 1560 Sherbrooke St. \\ East, Room Y-5634, Montreal (Que) H2L 4M1 Canada. Tel: (514) 2816000 ext \\ 6615; fax: (514) 896 4689; Email: bertrand@ere.umontreal.ca
}

Received 1.10.97; revised 9.12.97; accepted 19.1.98

Edited by J. Cidlowski
Keywords: Bax; cancer chemotherapy; caspase; lymphoma; apoptosis

\begin{abstract}
Abbreviations: CPT, camptothecin; VP16, etoposide; DABCYLYVADAPV-EDANS, 4-(4-dimethylaminophenylazo)benzoyl-TyrVal-Ala-Asp-Ala-ProVal-5-[(2-aminoethyl)amino]-naphthalene-1sulfonic acid; Ac-DEVD-AMC, Ac-Asp-Glu-Val-Asp-amino-4methylcoumarin; Ha-tag, hemagglutinin epitope tag; PARP, poly(ADPribosyl) polymerase.
\end{abstract}

\section{Introduction}

Programmed cell death (apoptosis) is a fundamental process essential for normal regulation of cell homeostasis and seems to play an important role in tumor development and progression (Raff et al, 1994; Thompson, 1995; Wyllie, 1997). All of the anticancer drugs used in clinic can induce apoptosis in various cell lines but the mechanisms by which these drugs activate programmed cell death are just beginning to be examined (Hickman, 1996; Reed, 1995). Several studies have provided major evidence that specific genes can act either as inhibitor or activator in the apoptotic process. The human Ced-9/Bcl-like family includes a series of related gene products that either inhibits apoptosis such as Bcl-2 (Hockenbery et al, 1990; Korsmeyer, 1992; Reed, 1997; Vaux et al, 1988), Bcl-xL (Boise et al, 1993), Mcl-1 (Kozopas et al, 1993), A1 (Lin et al, 1993), Bag (Takayama et al, 1995, 1996), Bfl-1 (Choi et al, 1995), Bcl-w (Gibson et al, 1996) and Brag-1 (Das et al, 1996), while others such as Bax (Oltvai et al, 1993), Bcl-xS (Boise et al, 1993), Bak (Chittenden et al, 1995; Farrow et al, 1995; Kiefer et al, 1995), Bad (Yang et al, 1995), Bik (Boyd et al, 1995), and Bid (Wang et al, 1996) are associated with the activation of apoptosis. Bcl-2 has been found translocated [t(14:18)] in human $B$ cell lymphoma and is thought to contribute to the development of B-cell neoplasia (Clarke et al, 1986; Tsujiimoto et al, 1984), while $\mathrm{bcl}-\mathrm{xL}$ is found often highly expressed in B lymphoma tumor cells (Xerri et al, 1996). Bcl-2 and Bcl-xL are also associated with cell death protection after treatment with anticancer compounds (Datta et al, 1995; Dole et al, 1995; Fang et al, 1995; Hockenbery, 1995; Ibrado et al, 1996; Korsmeyer, 1995; Reed, 1995) and recent observations suggested that Bax- $\alpha$ (Chresta et al, 1996; Krajewski et al, 1995; Sakakura et al, 1996; Thomas et al, 1996; Wagener et al, 1996) and Bcl-xS (Ealovega et al, 1996; Sumantran et al, 1995) may inhibit protective effects conferred by Bcl2 and $\mathrm{Bcl}-\mathrm{xL}$ and accelerate cell death induced by some anticancer drugs. 
An emerging family of Ced-3/lce-like cysteine proteases (caspases) has been also identified and several studies have revealed their importance in executing the process of cell death itself. The caspases are separated in three subfamilies based on their degrees of homology and by phylogenetic analysis; the ICE-related family includes Ice/ caspase-1 itself with its spliced isoforms (Alnemri et al, 1995; Yuan, 1993), Tx/lch-2/lce rel-II/caspase-4 (Faucheu et al, 1995; Kamens et al, 1995; Munday et al, 1995), Ty/ Ice rel-III/caspase-5 (Faucheu et al, 1996; Munday et al, 1995) and Ich-3/caspase-11 (Wang et al, 1996); the CPP32-related family includes CPP32/Yama/Apopain/caspase-3 (Fernandes-Alnemri et al, 1994; Nicholson et al, 1995; Tewari et al, 1995), Mch-2/caspase-6 (FernandesAlnemri et al, 1995), Mch-3/lce-Lap3/Cmh-1/caspase-7 (Duan et al, 1996a; Fernandes-Alnemri et al, 1995; Lippke et al, 1996), Mch-4/caspase-10 (FernandesAlnemri et al, 1996), Mch-5/Flice/Mach/caspase-8 (Boldin et al, 1996; Fernandes-Alnemri et al, 1996; Muzio et al, 1996) and the third group includes Ich-1[and s]/caspase-2 (Wang et al, 1994) and Ice-Lap6/Mch6/caspase-9 (Duan et al, 1996b).

Chemotherapeutic drugs such as DNA topoisomerase I (top 1) and II (top 2) inhibitors (camptothecin, CPT; etoposide, VP16, respectively) trigger apoptosis in various cell lines (Barry et al, 1990; Bertrand et al, 1991, 1993; Del Bino et al, 1992; Jaxel et al, 1988; Kaufmann, 1989; Solary et al, 1993; Walker et al, 1991). These drugs are known to stabilize a transient intermediate of topoisomerase reactions where enzymes are linked to the $3^{\prime}$ (top 1) or 5' (top 2) terminus of a DNA duplex producing DNA single- or double-strand breaks (Gupta et al, 1995; Pommier, 1997). The unknown signals emerging from DNA damage induced by chemotherapy drugs like DNA topoisomerase inhibitors are influenced by a series of checkpoints and are related to specific gene expression. Although it has been proposed that $B a x-\alpha$ is a wild-type p53 response gene, DNA topoisomerase inhibitors are able to trigger apoptosis in p53 mutated and null cells. Thus, to analyze further the relation between Bax- $\alpha$ expression, drug sensitivity and caspase activation, we have developed human B lymphoma Namalwa variant lines that express differential levels of Bax- $\alpha$ protein.

In this paper we show that Bax- $\alpha$ accelerates apoptosis induced by CPT (DNA topoisomerase I inhibitor), VP16 (DNA topoisomerase II inhibitor) and vinblastine (a tubulin polymerization inhibitor) even at very low drug concentration. The promoting cell death activity of Bax- $\alpha$ correlates also with its level of expression. Bax- $\alpha$ does not interfere with primary mechanism of action of DNA topoisomerase inhibitor CPT and acts downstream of DNA damagemediated DNA synthesis inhibition. However, Bax- $\alpha$ acts upstream of caspase and DNA fragmentation induction and accelerates the activation of caspase 3-like at low drug concentration. Taken together, these results suggest that Bax $-\alpha$ acts primarily downstream of the primary effect of chemotherapy drugs such as CPT and sensitizes B lymphoma cells to a series of anticancer drugs. Bax- $\alpha$ functions also upstream of caspase 3-like in the apoptotic process and accelerates their activation.

\section{Results
Expression of Bax- $\alpha$ and $B c l-x L$ in Namalwa cell lines

The human B lymphoma Namalwa cells are p53 double mutant cells (O'Connor et al, 1993) that contain two copies of the Epstein -Barr virus (EBV) genome integrated in opposite orientations on chromosome 1 (Lawrence et al, 1988). The Namalwa cells are characterized by their absence of EBV episomes and the lack of virus replication in response to inducers (Klein and Dombos, 1973; Matsuo et al, 1984). These cells express nuclear antigen proteins belonging to the EBNA-3 family, which expression was proposed to play a role to maintain the lymphoblastoid cells in an immortalized state (Luka et al, 1978; Sawada et al, 1989) although a causal role for EBV in tumor development remains obscure (Horner et al, 1995). However, these cells do not express the latent membrane proteins of the LMP family (Sample et al, 1989) and the $\mathrm{Bcl}-2$ homolog protein BHFR1, which expression is primarily linked with virus replication and lytic induction (Pearson et al, 1987) and more often associated with nasopharyngeal carcinoma (Horner et al, 1995). Moreover, these cells show high molecular weight and oligonucleosomesized DNA fragmentation patterns typical of apoptosis after short DNA damaging agent treatments (Sane et al, 1997) and express members of the Ced-9/Bcl-like family, such as Bcl-2, $\mathrm{Bax}-\alpha$ and $\mathrm{Bcl}-\mathrm{xL}$ (Figure 1, lower panels). To analyze the effect of Bax- $\alpha$ expression on drug response and caspase activation in human $B$ lymphoma cells, we have developed Namalwa variant lines that express differential levels of Bax- $\alpha$ protein. A Namalwa variant line that overexpress Bcl-xL was also derived to compare their effects. The human Bax- $\alpha$ and Bcl-xL cDNAs were first amplified by RT - PCR and inserted in a modified pCEP4 vector containing Kosak and hemagglutinin epitope tag sequences (HA-tag). After transfection, Namalwa cells were selected as bulk culture under hygromycin $(500 \mu \mathrm{g} /$ $\mathrm{ml}, 1.5 \mathrm{mg} / \mathrm{ml}$ ) and selection were maintained for about 2 months to obtain stable lines prior to perform the experiments. Control Namalwa cells did not survive under hygromycin selection. Western blot analysis indicates that the HA-Bax- $\alpha$ protein is expressed at different levels with respect to hygromycin concentration (Figure 1, upper left panel). The highest expression of HA-Bax- $\alpha$ has been found in transfected cells selected at $1.5 \mathrm{mg} / \mathrm{ml}$ hygromycin. High level of expression of $\mathrm{HA}-\mathrm{Bcl}-\mathrm{xL}$ was also achieved in cells selected at $1.5 \mathrm{mg} / \mathrm{ml}$ hygromycin (Figure 1, upper right panel). Protein expression was also visualized by immunohistochemical staining and micrographs show that all cells express the HA-epitope tagged Bax- $\alpha$ and Bcl-xL proteins (Figure 2).

\section{Effect of Bax- $\alpha$ upon apoptosis and DNA fragmentation}

To test Bax- $\alpha$ activity in the selected transfected cell lines, we first determined HA-Bax- $\alpha$ potency to promote cell death in cells grown in low serum concentration $(0.1 \%)$ or triggered with an anti-CD95/Fas antibodies for $24 \mathrm{~h}$ (Figure 3). We routinely used a filter DNA binding assay to monitor and quantitate kinetics of DNA fragmentation in cells undergoing apoptosis (Bertrand et al, 1991, 1995; Bertrand and Pommier, 

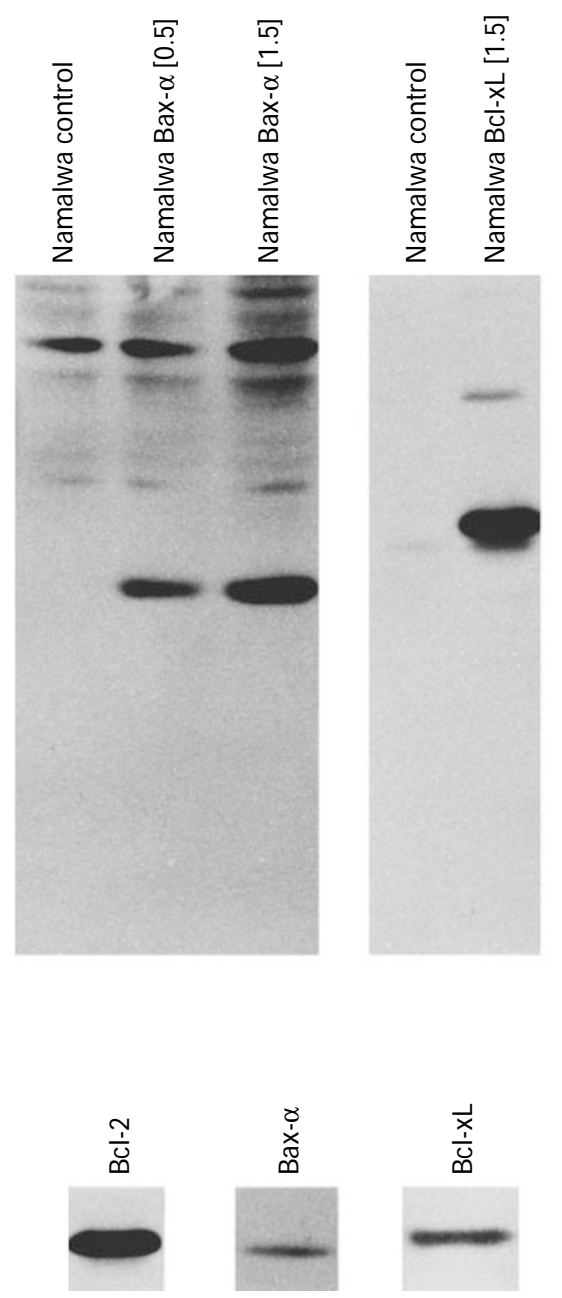

Figure 1 Expression of Bcl-related proteins in Namalwa cells. Upper panels. Cytosolic extracts were prepared as described in Materials and Methods from control, HA-Bax- $\alpha$ transfected Namalwa cells selected at $0.50 \mathrm{mg} / \mathrm{ml}$ and $1.5 \mathrm{mg} / \mathrm{ml}$ hygromycin (left panel) and HA-Bcl-xL transfected cells selected at $1.5 \mathrm{mg} / \mathrm{ml}$ hygromycin (right panel). Following SDS-polyacrylamide gel electrophoresis and electrophoretic transfer, HA-Bax- $\alpha$ and $\mathrm{HA}-\mathrm{Bcl}-\mathrm{xL}$ proteins were detected using anti-HA peptide monoclonal antibodies. Visualization of signals was performed by ECL and autoradiography (lower panels). Cytosolic extracts were prepared from control Namalwa cells. Following SDS-polyacrylamide gel electrophoresis and electrophoretic transfer, Bcl-2, Bax- $\alpha$ and $\mathrm{Bcl}-\mathrm{xL}$ proteins were detected using specific antibodies. Visualization of signals was performed by ECL and autoradiography

1995). Higher expression of Bax- $\alpha$ in Namalwa cells increases rates of DNA fragmentation both in cells grown in low serum concentration $(0.1 \%)$ and in the presence of anti-CD95/Fas antibodies for $24 \mathrm{~h}$ (Figure 3). The amount of DNA fragmentation has been found higher in cells expressing the highest level of Bax- $\alpha$ protein.

To analyze the effect of Bax- $\alpha$ upon anticancer druginduced apoptosis we first evaluated the effect of CPT, a DNA topoisomerase I inhibitor, in control and Bax- $\alpha$ transfected Namalwa variant lines. Several studies have shown that CPT, a DNA topoisomerase I inhibitor, activates the morphological changes and internucleosomal DNA fragmentation associated with apoptosis. Short treatments
(30 min) with CPT at moderate concentrations $(0.1 \mu \mathrm{M}-$ $0.5 \mu \mathrm{M})$ induced apoptosis in control Namalwa cells while low concentration of CPT such as $0.01 \mu \mathrm{M}$ does not trigger apoptosis significantly (Figure 4). However in the Bax- $\alpha$ transfected Namalwa cells, both the kinetic and extent of DNA fragmentation were more pronounced after CPT treatment at low concentration (Figure 4). Moreover, the promoting cell death activity of Bax- $\alpha$ after such treatment was more pronounced in cells selected at $1.5 \mathrm{mg} / \mathrm{ml}$ hygromycin, expressing the highest level of Bax- $\alpha$. At $0.01 \mu \mathrm{M}$ and $0.05 \mu \mathrm{M}$ CPT, the promoting cell death effect of Bax- $\alpha$ in the transfected lines was relatively more pronounced compared to the effect of CPT in control Namalwa cells. At higher CPT concentration $(0.1 \mu \mathrm{M}$ and $0.5 \mu \mathrm{M})$ the difference between the CPT-treated control and Bax- $\alpha$ transfected Namalwa cell line selected at $1.5 \mathrm{mg} / \mathrm{ml}$ hygromycin seems to be less pronounced (Figure 4) and no significant differences were detected in the Bax- $\alpha$ variant line selected at $0.5 \mathrm{mg} / \mathrm{ml}$ hygromycin when compared to Namalwa cells (data not shown). These results indicate a direct relation between the amount of $\mathrm{Bax}-\alpha$ and the degree of apoptosis induced by low concentration CPT. Thus, higher level of Bax- $\alpha$ sensitizes these cells to low drug concentration. For comparison, Namalwa cells transfected with $\mathrm{HA}-\mathrm{Bcl}-\mathrm{xL}$ and selected at $1.5 \mathrm{mg} / \mathrm{ml}$ hygromycin, are completely resistant to CPT-induced apoptosis (Figure 4; open circles).

CPT traps and stabilizes an intermediate of DNA topoisomerase I reaction when the enzyme is covalently linked to DNA. Stabilization of these cleavable complexes induces DNA strand breaks. These enzyme-linked DNA adducts on active replication forks inhibit DNA synthesis. DNA replication inhibition is one of the most widely explored processes to be implicated in the cytotoxic mechanism of action of DNA topoisomerase I inhibitors (Gupta et al, 1995). To determine whether Bax- $\alpha$ acts primarily upstream or downstream of CPT translated effect on DNA synthesis, rates of DNA synthesis were measured by thymidine pulse incorporation immediately after CPT treatments. Table 1 shows that in Namalwa control cells, immediately following CPT treatment at $0.01 \mu \mathrm{M}, 0.05 \mu \mathrm{M}$, $0.1 \mu \mathrm{M}$ and $0.5 \mu \mathrm{M}$, DNA synthesis rates were reduced to approximately $85,75,65$ and $59 \%$ to that of control untreated cells, respectively. The extent of DNA synthesis reduction was similar in the two transfected Namalwa cells treated with the same concentrations of CPT with rates of DNA synthesis of approximately $80,72,64$ and $57 \%$ to that of Bax- $\alpha$ transfected untreated cells, respectively. These results suggest that $B a x-\alpha$ does not interfere with the primary mechanism of action of CPT and does not amplify CPT-induced DNA synthesis inhibition.

Modulation of cell death by Bax- $\alpha$ was also observed in cells treated with VP-16 (DNA topoisomerase II inhibitor) and vinblastine (tubulin polymerization inhibitor). The promoting death activity of Bax- $\alpha$ was more pronounced in the variant line expressing the highest level of Bax- $\alpha$ (Figure 5) at low VP-16 and vinblastine concentrations. While the control Namalwa cells do not show significant DNA fragmentation when treated at or below $20 \mu \mathrm{M}$ VP-16 and vinblastine, in the high Bax- $\alpha$ expressing cells more 


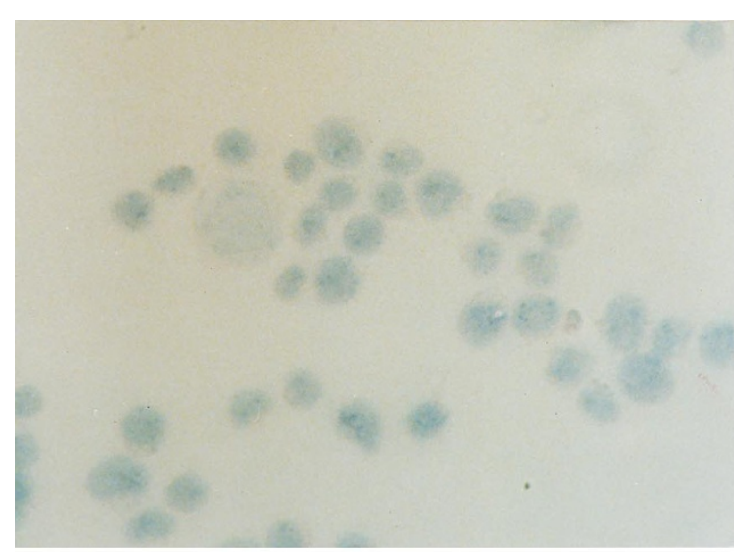

Namalwa control

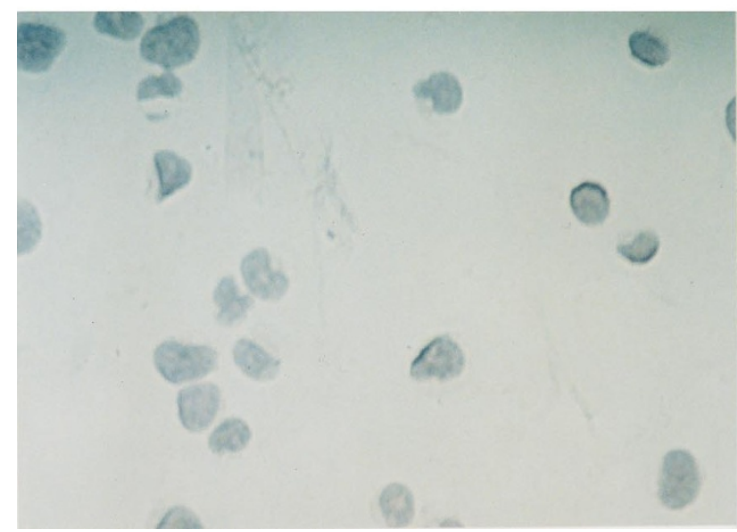

Namalwa control

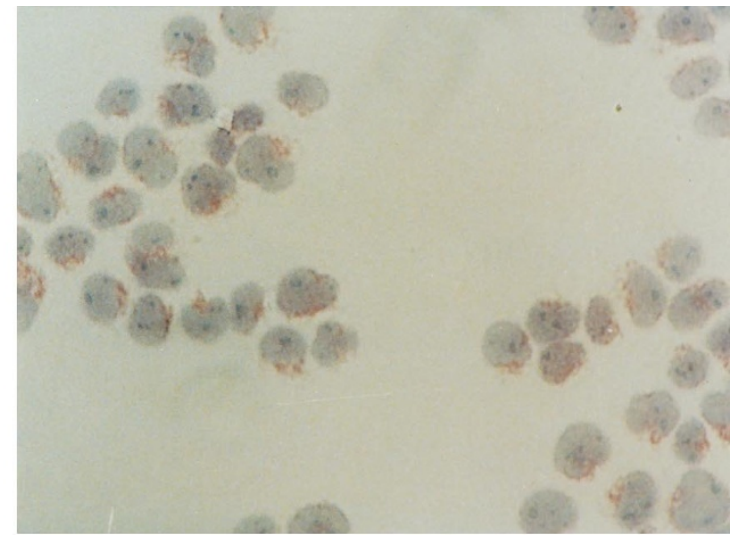

Namalwa Bax- $\alpha$

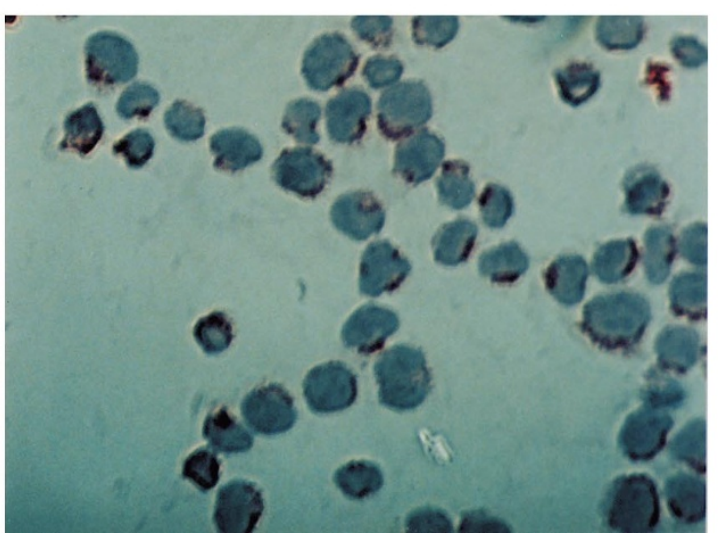

Namalwa Bcl-xL

Figure 2 Immunohistochemical revelation of the HA-Bax- $\alpha$ and $\mathrm{HA}-\mathrm{Bcl}-\mathrm{xL}$ proteins in transfected Namalwa variant cells. Upper panels are control Namalwa (left) and HA-Bax- $\alpha$ transfected Namalwa cells (right). Lower panels are control Namalwa (left) and HA-Bcl-xL transfected Namalwa cells (right)

than $70 \%$ DNA fragmentation was detected $8 \mathrm{~h}$ after drug treatment (Figure 5). As with CPT, these results show that higher level of Bax- $\alpha$ sensitizes these cells to low VP-16 and vinblastine concentrations. Conversely, overexpression of Bax- $\alpha$ did not significantly sensitize these cells to paclitaxel and cis-platinum(II) diammine dichloride treatment neither $8 \mathrm{~h}$ nor $24 \mathrm{~h}$ after drug treatment (Figure 5). To confirm the specificity of the DNA fragmentation observed by the filter assay, we visualized the intensity of the oligonucleosome-sized DNA fragments caused by these drugs in Namalwa and Namalwa-Bax cells (Figure 6). Overexpression of $\mathrm{Bcl}-\mathrm{xL}$ in these cells completely abrogates the occurrence of DNA fragmentation (Figure 6).

\section{Effect of Bax- $\alpha$ on caspase activation}

A series of caspases are involved in the apoptotic process (Kumar and Lavin, 1996; Patel et al, 1996). To determine whether Bax- $\alpha$ accelerates caspase activation, we monitored caspase 1-like and caspase 3-like activities using specific fluorogenic peptide substrates. In cytosolic extracts obtained from Namalwa cells, a slow increase in caspase 3-like activity was detected after $0.05 \mu \mathrm{M}$ CPT or $10 \mu \mathrm{M}$ VP16 treatment (Figure 7). The kinetic of caspase 3-like activity correlates with the slow activation of DNA fragmentation following CPT and VP-16 treatment in control Namalwa cells (Figures 4 and 5). In contrast, in Bax- $\alpha$ transfected Namalwa cells a rapid increase in caspase 3-like activity was detected following CPT and VP. 16 treatment (Figure 7). These results suggest that caspase 3-like activity correlates with occurrence of DNA fragmentation and that $B a x-\alpha$ accelerates caspase 3 -like activation. No increase in DABCYL-YVADAPV-EDANS hydrolysis was detected following CPT and VP-16 treatment in both cell lines suggesting that caspase 1-like activity be neither activated nor involved in the apoptotic process induced by CPT and VP-16 in these cells. Moreover, caspase 3 activation was not detected in cells overexpressing the HA-Bcl-xL protein after CPT and VP-16 treatment (data not shown). These observations are consistent with the protective effect conferred by $\mathrm{Bcl}-\mathrm{xL}$ in these cells.

To validate these findings, kinetic of poly(ADPribosyl) polymerase (PARP) cleavage, a known substrate of caspase 3-like activity (Lazebnik et al, 1994), was monitored in control and Bax- $\alpha$ transfected Namalwa cells 


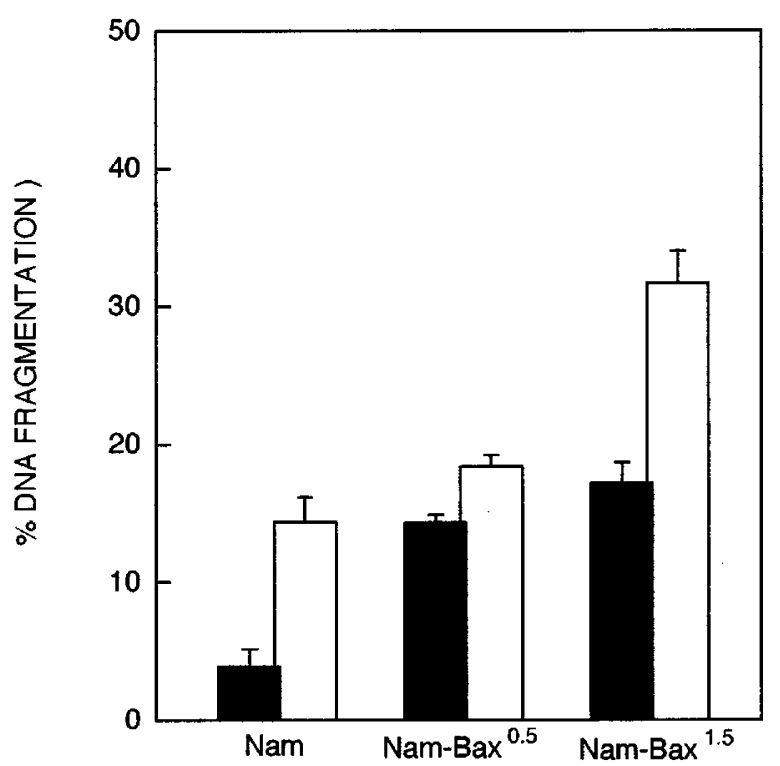

Figure 3 Bax- $\alpha$ promotes DNA fragmentation in cells grown in low serum and in presence of $\mathrm{CD} 95 /$ Fas antibodies. ${ }^{14} \mathrm{C}$-Thymidine-labeled cells were grown for $24 \mathrm{~h}$ in $0.1 \%$ heat inactivated serum (close bars) and in the presence of anti-CD95/FAS antibodies (open bars). DNA fragmentation was determined by filter elution assays. Results are expressed as percentage DNA fragmentation relative to untreated cells grown in $10 \%$ heat inactivated serum. Bars represent the means \pm S.E. of a triplicate experiment

treated with VP-16. Figure 8 shows that PARP cleavage and the appearance of the small $24 \mathrm{kDa}$ fragment occurs much more extensively in VP-16-treated Bax- $\alpha$ transfected Namalwa cells compared to that of VP-16-treated control Namalwa cells. Taken together, our results suggest that Bax- $\alpha$ accelerate the processing and activation of caspase 3-like at low drug concentrations.

\section{Discussion}

The human Bax gene belongs to the Ced-9/Bcl-like familiy that regulates cell survival and cell death. Several mRNA isoforms have been isolated and derived likely from alternative splicing of a single Bax gene mapped to human chromosome 19q13.3-q13.4 (Apte et al, 1995; Oltvai et al, 1993). The first study with Bax gene product indicated that Bax $\alpha$ has a cell death promoting activity, inhibiting the protective effect conferred by $\mathrm{Bcl}-2$ in an interleukine (IL)-3 dependent cell line upon cytokine removal (Oltvai et al, 1993). Immunohistochemical analysis of Bax expression in mice showed that Bax proteins are expressed in a wide variety of cell types and predominantly in a variety of epithelial cells, in the thymic medulla and in the germinal center lymphocytes of lymph nodes and in several population of reproductive and neuronal cells (Krajewski et al, 1994). Yeast two-hybrid assays indicated that $\mathrm{Bax}-\alpha$ interacts and heterodimerizes with itself, Bcl-2, Bcl-xL, Mcl-1 and A-1 (Sedlak et al, 1995). Bax-deficient mice displayed thymocytes and $B$ cells hyperplasia and disordered ovaries granulosa cells, atypical male germ cells and no mature haploid sperm (Knudson et al,

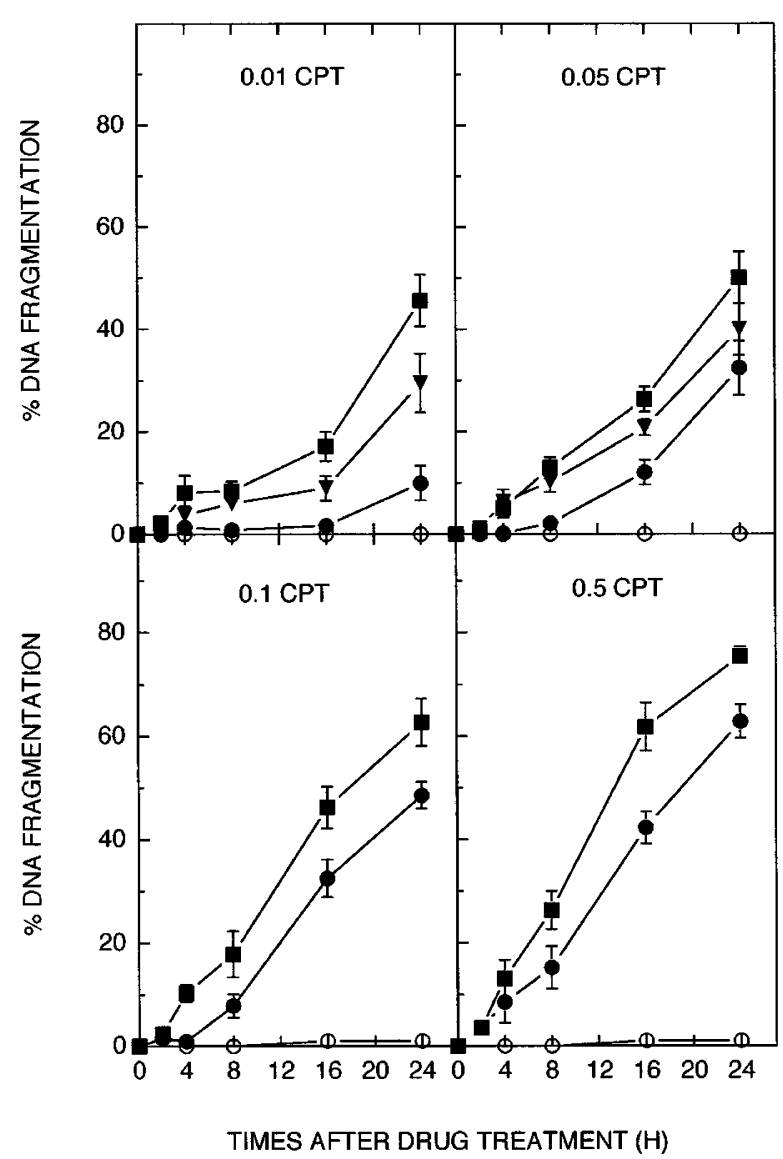

Figure 4 The effects of overexpression of Bax- $\alpha$ in Namalwa cells treated at various CPT concentrations. ${ }^{14} \mathrm{C}$-Thymidine-labeled cells were treated for $30 \mathrm{~min}$ with 0.01 (upper left panel), 0.05 (upper right panel), 0.1 (lower left panel) and $0.5 \mu \mathrm{M}$ CPT (lower right panel). After drug removal, cells were incubated in drug free-medium and at the indicated times ( $x$ axis; hour), DNA fragmentation was determined by filter elution assays. Results are expressed as percentage DNA fragmentation relative to that of untreated cells. Points represent the means $\pm S$.E. of four independent experiments performed in duplicate. Symbols are Namalwa cells $(\mathbf{O})$; Bax- $\alpha$ transfected Namalwa cells selected at $0.50 \mathrm{mg} / \mathrm{ml}(\boldsymbol{\nabla})$ and $1.5 \mathrm{mg} / \mathrm{ml}$ hygromycin $(\boldsymbol{\square})$. For comparison, $\mathrm{Bcl}-\mathrm{xL}$ transfected cells selected at $1.5 \mathrm{mg} / \mathrm{ml}$ hygromycin $(O)$. The difference in rate of DNA fragmentation between the variant lines and control cells was statistically significant at $4,8,16$ and $24 \mathrm{~h}$ after drug treatment $(0.001<P<0.03$; student $t$-test values; except for values at $24 \mathrm{~h}$ in HA-Bax selected at $0.5 \mathrm{mg} / \mathrm{ml}$ hygromycin in the upper right panel)

Table 1 Rates of DNA synthesis after camptothecin in control and transfected Namalwa cells

\begin{tabular}{lccc}
\hline CPT & Namalwa & Nam-bax $^{\mathbf{0 . 5 0}}$ & Nam-bax $^{\mathbf{1 . 5 0}}$ \\
\hline $0.01 \mu \mathrm{M}$ & $85.0 \pm 9.9$ & $80.5 \pm 9.8$ & $80.7 \pm 3.8$ \\
$0.05 \mu \mathrm{M}$ & $74.7 \pm 5.8$ & $73.7 \pm 5.2$ & $71.2 \pm 10.9$ \\
$0.10 \mu \mathrm{M}$ & $65.5 \pm 6.4$ & $64.7 \pm 2.9$ & $63.5 \pm 8.2$ \\
$0.50 \mu \mathrm{M}$ & $59.2 \pm 7.5$ & $56.2 \pm 4.8$ & $57.5 \pm 4.8$ \\
\hline
\end{tabular}

Cells were treated with various concentrations of CPT for $30 \mathrm{~min} .{ }^{3} \mathrm{H}$-thymidine labeled incorporation were determined by 10 min pulse experiments. Values are expressed as \% of DNA synthesis relative to control untreated cells and represent the means \pm S.E. of two independent experiments performed in triplicate $(n=6)$. Nam -bax ${ }^{0.50}$ and Nam- bax ${ }^{1.50}$ mean Namalwa cells transfected with Bax and selected at $0.50 \mathrm{mg} / \mathrm{ml}$ and $1.5 \mathrm{mg} / \mathrm{ml}$ hygromycin, respectively 


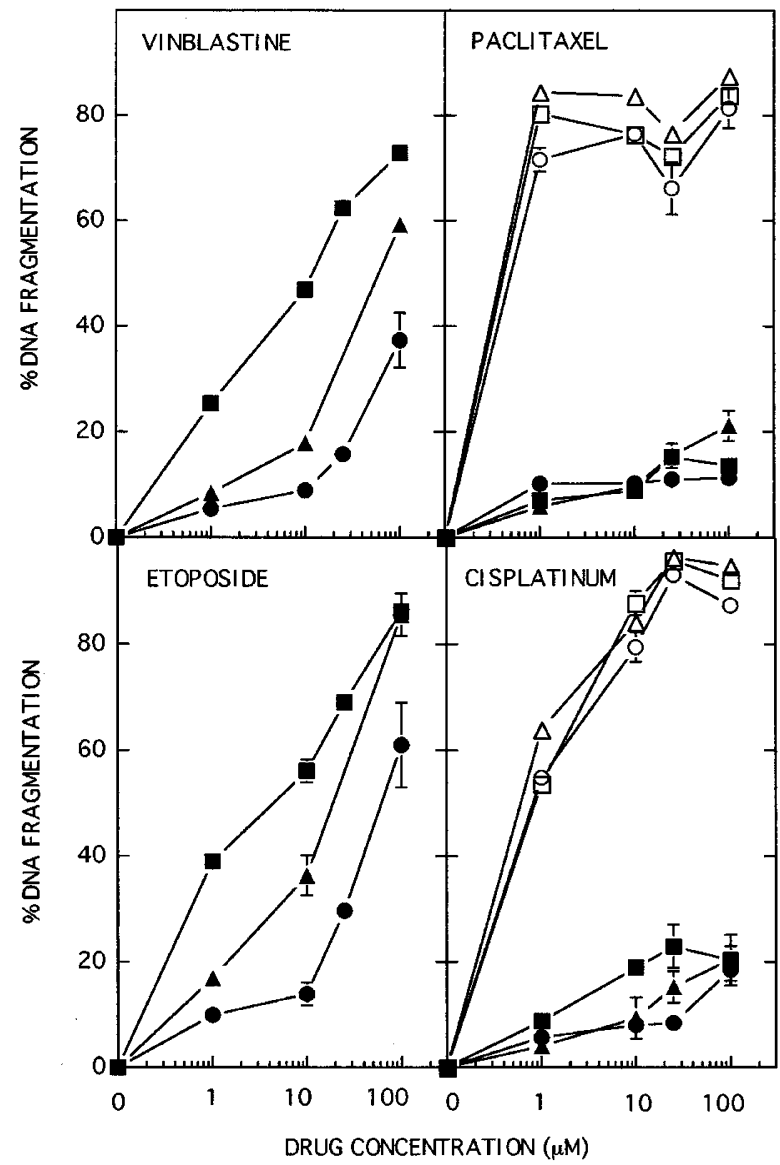

Figure 5 Activation of DNA fragmentation in control and Bax- $\alpha$ transfected Namalwa cells following VP-16, vinblastine, paclitaxel and cis-platinum treatments. ${ }^{14} \mathrm{C}$-Thymidine-labeled cells were treated for $8 \mathrm{~h}$ (close symbols) or $24 \mathrm{~h}$ (open symbols) with various concentrations of vinblastine (upper left panel), VP-16 (lower left panel), paclitaxel (upper right panel) and cis-platinum (lower right panel). DNA fragmentation was determined by filter elution assays. Results are expressed as percentage DNA fragmentation relative to that of untreated cells. Points represent the means $\pm S$.E. of three experiments performed in triplicate. Symbols are Namalwa control cells $(\bullet, O)$ and Bax- $\alpha$ transfected Namalwa cells selected at $0.5 \mathrm{mg} / \mathrm{ml}$ hygromycin $(\boldsymbol{\Delta}, \triangle)$ and $1.5 \mathrm{mg} / \mathrm{ml}$ hygromycin $(\boldsymbol{\square}, \square)$. The difference in rate of DNA fragmentation between the variant lines and control cells was statistically significant for vinblastine and etoposide treated cells $(0.0001<P<0.03$; student $t$-test values)

1995). Thus, low Bax expression may result in hyperplasia and plays a role in tumor development.

In this study, by selecting transfected B-lymphoma Namalwa variant cells that express differential level of Bax- $\alpha$, we show that its effect is directly related to its level of expression. Reduced expression of Bax was associated recently with poor response rates to chemotherapy in women with metastatic breast adenocarcinoma (Bargou et al, 1995). Gene transfer studies in human breast cell lines showed that Bax- $\alpha$ sensitized these cells to radiation- and drug-induced apoptosis (Sakakura et al, 1997; Wagener et al, 1996). Other studies have indicated that the Bax: Bcl-2 ratio in human testicular tumors and $B$-cell chronic lymphocytic leukemia is related to cell susceptibility to
Namalwa

$123456 \mathrm{M}$

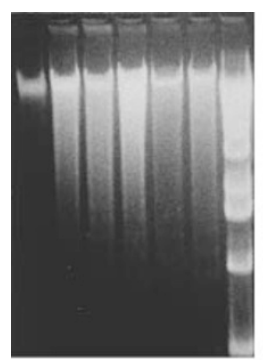

Nam- Bax

$123456 \mathrm{M}$

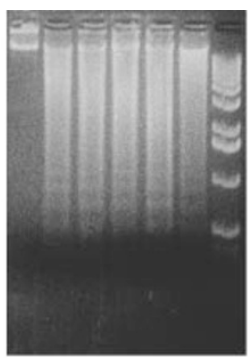

Nam-Bcl-xL

123456

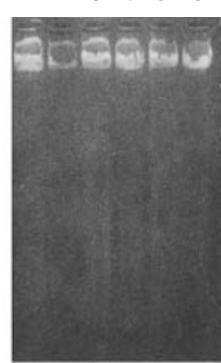

Figure 6 Analysis of DNA fragmentation by agarose gel electrophoresis. Oligonucleosome-sized DNA fragments were visualized following standard agarose gel electrophoresis by ethidium bromide staining. (1) untreated cells; (2) $0.05 \mu \mathrm{M} \mathrm{CPT}$; (3) $1.0 \mu \mathrm{M} \mathrm{VP-16;} \mathrm{(4)} 1.0 \mu \mathrm{M}$ cisplatinum; (5) $1.0 \mu \mathrm{M}$ vinblastine; (6) $1.0 \mu \mathrm{M}$ paclitaxel. Treatments were of $16 \mathrm{~h}$ for Namalwa cells, $8 \mathrm{~h}$ for HA-Bax- $\alpha$ and $24 \mathrm{~h}$ for HA-Bcl-xL variant Namalwa cells

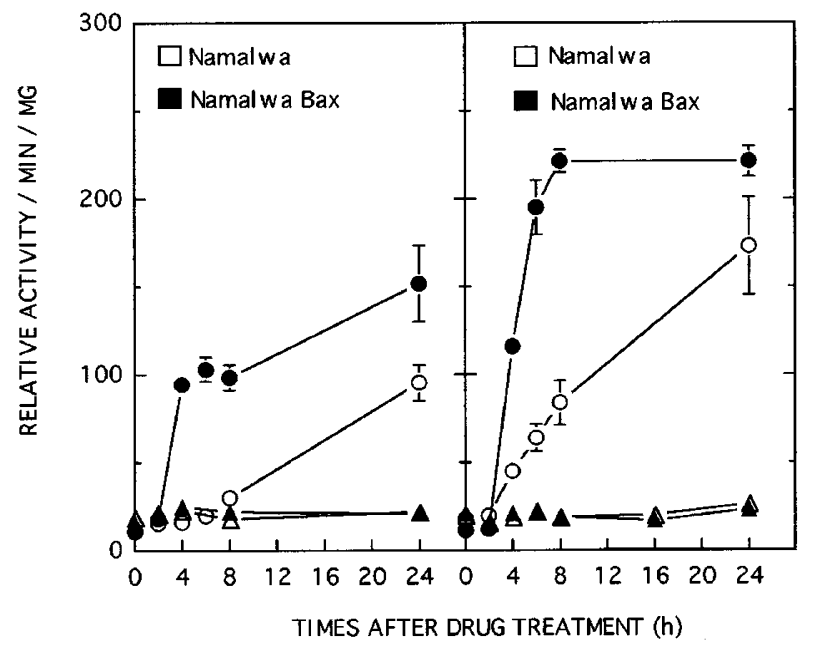

Figure 7 Caspase 1-like and caspase 3-like activities in CPT and VP-16 treated control and Bax- $\alpha$ transfected Namalwa cells. Cytosolic extracts were prepared from control (open symbols) and Bax- $\alpha$ transfected Namalwa cells (close symbols) at the indicated times following CPT $(0.05 \mu \mathrm{M}$; left panel) and VP-16 $(10 \mu \mathrm{M}$; right panel) treatment. Caspase activities were monitored continuously at $37^{\circ} \mathrm{C}$ by detecting fluorescence emission in the presence of DABCYL-YVADAPV-EDANS using excitation wavelength of $360 \mathrm{~nm}$ and emission wavelength of $490 \mathrm{~nm}$ and AC-DEVD-AMC at an excitation wavelength of $380 \mathrm{~nm}$ and emission wavelength of $460 \mathrm{~nm}$. Enzyme activities were measured as initial velocities and expressed as relative intensity $/ \mathrm{min} / \mathrm{mg}$. Points represent the means \pm S.E. of three independent determinations. Symbols used are $(\boldsymbol{\Delta}, \triangle)$ caspase 1-like activity; $(\mathbf{O}, \bigcirc)$ caspase 3-like activity

undergo apoptosis (Chresta et al, 1996; McConkey et al, 1996; Thomas et al, 1996). Ordered balance within the ratio of effector and repressor proteins regulating the decision of a cell to survive or die has already been suggested to form an important checkpoint for cell death (Oltvai and Korsmeyer, 1994). Our results are consistent with that model and indicate that the level of expression of Bax- $\alpha$ might be an important control point regulating anticancer drug sensitivity in tumor cells. Others have reported also that $\mathrm{Bax}-\alpha$ can antagonize the protective effects of $\mathrm{Bcl}-\mathrm{xL}$ during VP-16-induced apoptosis in FL5.12 cells and 


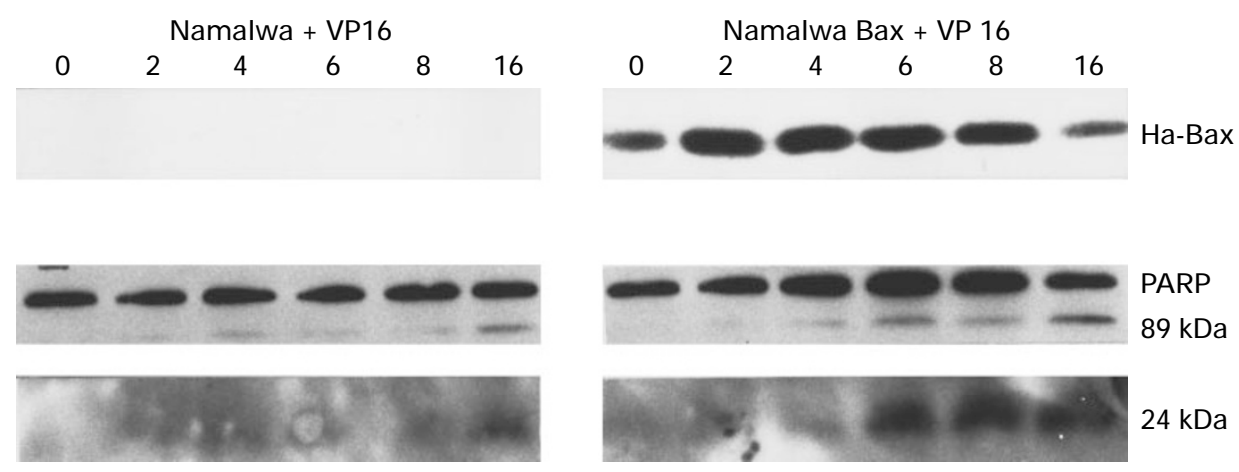

Figure 8 PARP cleavage in control and Bax- $\alpha$-transfected Namalwa cells following VP-16 treatment. Whole-cell extracts were prepared as described in Materials and Methods at the indicated times after VP-16 treatment $(10 \mu \mathrm{M})$ from Namalwa (left panel) and Bax- $\alpha$ transfected Namalwa cells selected at $1.5 \mathrm{mg} / \mathrm{ml}$ hygromycin (right panel). Following SDS-polyacrylamide gel electrophoresis (12\%) and electrophoretic transfer, HA-Bax- $\alpha$ expression and PARP cleavage were detected using specific antibodies. Visualization of signals was performed by ECL and autoradiography represent different exposition

interestingly in these cells, Bax- $\alpha$ was also much less potent to promote cell death induced by cisplatinum consistent with our observations in Namalwa cells (Simonian et al, 1996). Although our observations suggest that Bax- $\alpha$ does not promote paclitaxel-induced apoptosis in the $\mathrm{B}$ lymphoma Namalwa cells, others have reported that a mean of tenfold increased level of murine Bax expression in human SW626 ovarian cancer cells promotes cell death induced by paclitaxel (Strobel et al, 1996). No rationale explanation could be provided to explain the different observations, but the difference in paclitaxel sensitivity between these cell lines may reflect the presence or absence of other unknown factors that are involved in paclitaxel-induced apoptosis.

Our results indicate that Bax- $\alpha$ does not interfere with the primary mechanism of action of anticancer drugs such as CPT, since extent of DNA synthesis reduction is found similar in all Bax- $\alpha$ transfected and control cells following CPT treatment. Although signals emerging from unfinished replication and damaged DNA are not yet fully understood, this study and others, indicate that Bax- $\alpha$ is a control point and influences the decision of a cell to undergo apoptosis. It has been proposed that Bax- $\alpha$ is a wild-type p53 primary response gene, in p53-regulated pathway for apoptosis activation (Miyashita et al, 1994; Miyashita and Reed, 1995). The Namalwa cells are p53 double mutant cells (codon 248/exon 7; Arg to GIn/Arg to Trp) (O'Connor et al, 1993) and it is unlikely that mutated p53 plays a role in the induction of apoptosis in these lines. Nevertheless, gene transfer-mediated elevation of Bax- $\alpha$ sensitizes these cells to some but not all anticancer agents in a p53-independent manner. Moreover, the expression of EBNA-3 protein family in the Namalwa cells are unlikely to play a role in apoptosis regulation (Horner et al, 1995).

Activation of apoptotic proteases are known to be a critical step in dying cells. Series of caspases were reported to play a central role in executing apoptosis. In this study, we investigate the relation between Bax- $\alpha$ and the activation of caspases. We examined whether Bax- $\alpha$ accelerates the activation of the proteases required in the execution phase of apoptosis. Our experiments using fluorogenic substrates provide evidence that in cells undergoing apoptosis induced by CPT and VP-16, the activation of caspase- 3 like was accelerated in Bax- $\alpha$ transfected cells. No evidence of caspase 1-like activation was detected in these cells treated with CPT and VP-16. Caspase 3-like activation was also associated with PARP cleavage, a known substrate for these proteases (Lazebnik et al, 1994). Interestingly, the effect of Bax- $\alpha$ on caspase activation is opposite to that of Bcl-2 and Bcl-xL. Recent studies have reported that $\mathrm{Bcl}-2$ like $\mathrm{Bcl}-\mathrm{xL}$ prevents the activation of caspases in cultured cells (Monney et al, 1996; Shimizu et al, 1996). Activation of caspase 3 in Baxinduced cell death was reported recently in several studies (Deveraux et al, 1997; Kitanaka et al, 1997; Xiang et al, 1996). Interestingly, blocking caspase 3-like activities by the protease inhibitor N-benzyloxycabonyl-Val-Ala-Aspfluoromethylketone prevents the cleavage of nuclear and cytosolic substrates and DNA fragmentation but does not prevent cells to die by a necrosis-like mode of cell death (Hirsch et al, 1997; Xiang et al, 1996).

In summary, our results indicate that $B a x-\alpha$ is a primary controlpoint that promotes transmission of cell death signals emerging from DNA damage in a p53-independent manner and accelerates activation of an apoptotic protease cascade. The identification of cell death signals triggered by DNA damage in p53 mutant cells and understanding how Bax- $\alpha$ promotes caspase activation and DNA fragmentation, will certainly help to design in future new therapeutic strategies to circumvent drug resistance mechanisms in p53-independent pathway of apoptosis.

\section{Materials and Methods}

\section{Chemicals}

Radioactive precursors $\left[2-{ }^{14} \mathrm{C}\right]$ thymidine $(59 \mathrm{mCi} / \mathrm{mmol})$, and [methyl- ${ }^{3} \mathrm{H}$ ]thymidine $(78 \mathrm{Ci} / \mathrm{mmol})$ were obtained from ICN BioMedicals (Costa Mesa, CA). 20-S-camptothecin lactone, etoposide (VP16), vinblastine, paclitaxel and cis-platinum(II) diammine dichloride were purchased from Sigma Chemicals Co. (St Louis, MO) and dissolved in dimethyl-sulphoxide (at $10 \mathrm{mmol} / \mathrm{l}$ ) prior to each experiment. The fluorogenic peptide derivatives 4-(4-dimethylamino- 
phenylazo)benzoyl-Tyr-Val-Ala-Asp-Ala-Pro-Val-5-[(2-aminoethyl)amino]-naphthalene-1-sulfonic acid (DABCYL-YVADAPVEDANS) and Ac-Asp-Glu-Val-Asp-amino-4-methylcoumarin (AcDEVD-AMC) were purchased from Bachem Bioscience Inc. (King of Prussia, PA). Antibodies to human CD95/Fas receptor were obtained from Upstate Biotechnology (Lake Placid, NY). All other chemicals were of reagent grade and purchased either from Sigma, ICN and Boehringer-Mannheim or from other local sources.

\section{Cell culture and DNA labeling}

The human Namalwa cell line obtained from the American Type Culture Collection (Rockville, MD), were grown in suspension culture at $37^{\circ} \mathrm{C}$ in the presence of $5 \% \mathrm{CO} 2$ in RPMI- 1640 medium supplemented with $10 \%$ heat-inactivated fetal bovine serum, $2 \mathrm{mM}$ glutamine, $100 \mathrm{U} / \mathrm{ml}$ penicillin and $100 \mu \mathrm{g} / \mathrm{ml}$ streptomycin. Cell culture products were purchased from Gibco BRL Life Technologies (Grand Island, NY). For DNA labeling, Namalwa cells were grown with $\left[{ }^{14}\right.$-C]thymidine $(0.02 \mu \mathrm{Ci} / \mathrm{ml})$ for $24 \mathrm{~h}$ and then chased in isotope-free medium overnight prior to drug treatment.

\section{cDNA cloning and transfection}

The human Bax- $\alpha$ and $\mathrm{Bcl}-\mathrm{xL}$ cDNAs were cloned by RT-PCR from total RNA using specific adapter primers containing Notl sequences at the ATG start codon and TAA stop codon. The amplified fragments were first cloned in pCRII vector (TA cloning system; Invitrogen, San Diego, CA) and then subcloned at the Notl restriction site in the eucaryotic expression vector pCEP4 (InVitrogen) that has been modified to include consensus Kosak and hemagglutinin epitope Tag sequences (HA-Tag) between the BamHI and Notl restriction sites. Vectors were sequenced by ALF DNA sequencer (LKB-Pharmacia Biotech, Upsalla, Sweden) using both vector and internal primers. Purified pCEP4-HA-Bax, pCEP4-HA-Bcl-xL constructs and pCEP4mock vector were transfected in Namalwa cells by electroporation at 0.27 kVolts (Gene Pulser, BioRad, Hercules, CA). Transfected cells were grown under hygromycin selection for 2-3 months to obtain stable lines prior to perform the experiments. Control Namalwa cells do not survive under hygromycin selection. Drug sensitivity of control and pCEP4-mock transfected variant lines were identical. Restriction and modification enzymes were purchased either from Pharmacia or Gibco BRL.

\section{Western blot and immunohistochemistry analysis}

For Western blot, control and transfected Namalwa cells were collected by centrifugation, washed twice with ice-cold phosphatebuffered saline (PBS) and then homogenized in a lysis buffer containing $5 \mathrm{mM}$ HEPES pH 7.4, $160 \mathrm{mM} \mathrm{KCl}, 40 \mathrm{mM} \mathrm{NaCl}, 10 \mathrm{mM}$ $\mathrm{MgCl}_{2}, 1 \mathrm{mM} \mathrm{PMSF}, 0.5 \% \mathrm{NP} 40$ and a cocktail of protease inhibitors (Complete $^{\mathrm{TM}}$, Boehringer-Mannheim) at $4^{\circ} \mathrm{C}$ for 30 min with agitation. After centrifugation, supernatants were collected as cytosolic protein extracts. Protein concentrations were determined using the Bradford assay with bovine serum albumin as standard. Antibodies to the peptide epitope derived from the hemagglutinin protein of human influenza virus (HA epitope tag) and to human PARP protein were obtained from Boehringer-Mannheim. Affinity purified antibodies to human Bcl-2 and Bax were purchased from Santa Cruz Biotechnology, Inc (Santa Cruz, CA) and antibodies to $\mathrm{Bcl}-\mathrm{xL}$ were obained from CalBiochem (San Diego, CA). Enhanced cheminulescence detection of peroxidase-labeled secondary antibodies was performed using Amersham Life Science reagents. Expression of $\mathrm{HA}-\mathrm{Bax}$ and $-\mathrm{Bcl}-\mathrm{xL}$ by immunohistochemistry was visualized using anti-HA mouse monoclonal antibodies (Boehringer-Mannheim) as primary antibody $(10 \mu \mathrm{g} / \mathrm{ml})$, a biotinylated goat anti-mouse (Sigma) as secondary antibody $(10 \mu \mathrm{g} / \mathrm{ml})$ followed by a streptavidin-alcaline phosphatase complex (Sigma) and colorimetric reaction using FastRed TR/ Naphthol AS-MX (Sigma). Briefly, cells were spread by centrifugation on microscope slides and fixed in a solution containing $50 \%$ acetone and $50 \%$ methanol. Permeable cells were then incubated for $30 \mathrm{~min}$ in PBS buffered solution containing $10 \%(\mathrm{v} / \mathrm{v})$ goat serum and $5 \%(\mathrm{w} / \mathrm{v})$ bovine serum albumin (Sol A). Cells were then incubated with the primary antibody diluted in Sol A for $30 \mathrm{~min}$, followed by several washings with Sol $A$ and then incubated with the secondary antibodies diluted in Sol A. After several washes in Sol A, cells were incubated with a streptavidin-alcaline complex, washed again and incubated with a solution of FastRed TR/Naphthol As-MX according to the manufacturer's instructions (Sigma). Cells were then analyzed under an Axioscop camera-and equipped microscope (Carl Zeiss, West Germany).

\section{DNA filter elution assay}

DNA filter elution assays were designed to monitor and quantitate DNA fragmentation associated with apoptosis (Bertrand and Pommier, 1995). Each sample (approximately $0.5 \times 10^{6}{ }^{14} \mathrm{C}$-thymidine-labeled cells) is loaded onto a protein-adsorbing filter (vinyl/acrylic copolymers filters, Metricel membrane, $0.8 \mu \mathrm{m}$ pore size, $25 \mathrm{~mm}$ diameter, Gelman Sciences Inc., Ann Arbor, MI) mounted in a Millipore filter holder connected to a $50 \mathrm{ml}$ syringe. Cells are then washed with $5 \mathrm{ml}$ of phosphate buffered saline (PBS). As soon as the washing solution has dripped through by gravity, lysis is performed with $5 \mathrm{ml}$ of lysis solution ( $0.2 \%$ sodium sarkosyl - $2 \mathrm{M} \mathrm{Nacl}-0.04 \mathrm{M}$ EDTA, $\mathrm{pH} 10.0$ ). After the lysis has dripped through by gravity, it is washed from the filters with $5 \mathrm{ml}$ of $0.02 \mathrm{M} \mathrm{EDTA}(\mathrm{pH} 10.0)$. The filter is then processed as described (Bertrand and Pommier, 1995). Briefly, it was placed in a scintillation vial to which $1.0 \mathrm{ml}$ of $1 \mathrm{~N} \mathrm{HCl}$ is added. The vial is sealed and heated for $1 \mathrm{~h}$ at $60^{\circ} \mathrm{C}$ to depurinate the DNA. Then, $2.5 \mathrm{ml}$ of $0.4 \mathrm{~N} \mathrm{NaOH}$ is added and allowed to stand $1 \mathrm{~h}$ at room temperature to release the labeled DNA from the filters. Radioactivity was counted by liquid scintillation spectrometry in each fraction (loading wash, lysis, EDTA wash, filter). DNA fragmentation was determined as the fraction of DNA in the loading wash fraction+lysis fraction+EDTA wash fraction relative to total DNA (loading wash+lysis+EDTA wash+filter). Results are expressed as the percentage of DNA fragmented in treated cells compared to DNA fragmented in control untreated cells (background) using the formula:

$$
(F-F 0 / 1-F 0) \times 100
$$

where $\mathrm{F}$ and $\mathrm{FO}$ represent DNA fragmentation in treated and control cells, respectively.

\section{Analysis of DNA fragmentation by agarose gel electrophoresis}

To visualize the oligonucleosome-sized DNA fragments, at specified times after drug treatment cellular DNA was extracted by a salting-out procedure as described previously (Miller et al, 1988). Electrophoresis was done in $1.6 \%$ agarose gel in Tris-acetate buffer $(\mathrm{pH} 8.0)$. Following electrophoresis DNA was visualized by ethidium bromide staining.

\section{Measurement of thymidine incorporation}

Control and transfected Namalwa cells were prelabeled with ${ }^{14} \mathrm{C}$-thymidine $(0.02 \mu \mathrm{Ci} / \mathrm{ml})$ for $24 \mathrm{~h}$ and then chased in isotope-free 
medium overnight prior to drug treatment. Cells were incubated in CPT containing medium for $30 \mathrm{~min}$. After drug treatment, cells were washed twice with complete medium and rates of nucleotide incorporation were measured by $10 \mathrm{~min}$ pulse experiments with $\left[{ }^{3} \mathrm{H}\right]$ thymidine $(10 \mu \mathrm{Ci} / \mathrm{ml})$ as described (Bertrand et al, 1992). Nucleotide incorporation was stopped by adding $10 \mathrm{ml}$ of ice-cold PBS and cells were quickly pelleted by centrifugation $\left(1000 \mathrm{~g}, 3 \mathrm{~min}, 4^{\circ} \mathrm{C}\right)$. Acidinsoluble nucleotides were precipitated on ice with $10 \%$ trichloracetic acid. The precipitates were dissolved in $0.4 \mathrm{~N} \mathrm{NaOH}$ and radioactivity was monitored by scintillation spectrometry. Results were expressed as the ratio of $\left[{ }^{3}-\mathrm{H}\right] /\left[{ }^{14}-\mathrm{C}\right]$ for treated cells over the ratio of $\left[{ }^{3}-\mathrm{H}\right] /\left[{ }^{14}-\mathrm{C}\right]$ of untreated cells (Bertrand et al, 1992).

\section{Caspase activity determination}

Cytosolic extracts are prepared by washing control and transfected Namalwa cells twice by centrifugation/resuspension in $10 \mathrm{ml}$ ice-cold PBS (without $\mathrm{Ca}^{2+}$ and $\mathrm{Mg}^{2+}$ ). Cells are then homogenized at $4{ }^{\circ} \mathrm{C}$ for $30 \mathrm{~min}$ in a lysis buffer containing $100 \mathrm{mM}$ HEPES (pH 7.5), $5 \mathrm{mM}$ EDTA, $5 \mathrm{mM}$ DTT, $20 \%$ glycerol and $0.5 \%$ NP-40. Samples are then centrifuged ( $13000 \mathrm{~g}$ for $10 \mathrm{~min}$ at $4^{\circ} \mathrm{C}$ ) and supernatants collected as cytosolic extracts. Caspase activities were measured by monitoring fluorescence continuously in a dual luminescence fluoremeter (LS 50B Perkin Elmer) using excitation wavelength of $360 \mathrm{~nm}$ and emission wavelength of $490 \mathrm{~nm}$ for the substrate DABCYL-YVADAPV-EDANS and excitation wavelength of $380 \mathrm{~nm}$ and emission wavelength of $460 \mathrm{~nm}$ for the substrate Ac-DEVD-AMC. Reactions were carried out in cuvettes and temperature maintained at $37^{\circ} \mathrm{C}$ using a waterjacketed sample compartment. The assay mixture contained $100 \mathrm{mM}$ HEPES (pH 7.5), 20\% (v/v) glycerol, $5 \mathrm{mM}$ DTT, $5 \mathrm{mM}$ EDTA and $200 \mu \mathrm{M}$ fluorogenic peptides. Enzyme activities were determined as initial velocities and expressed as relative intensity $/ \mathrm{min} / \mathrm{mg}$.

\section{Acknowledgements}

RB is supported by the National Cancer Institute of Canada with funds from the Canadian Cancer Society (grant \# 006254) and by the Medical Research Council of Canada (grant \# MT 12125). ES is a recipient of a Canderel fellowship. GC was supported by a fellowship from the Ministere de l'Education du Québec. RB obtained scholarship from the Medical Research Council of Canada in association with the Research Cancer Society Inc. We would like to thank Dr AH Greenberg (Manitoba Institute of Cell Biology, Winnipeg, Manitoba) for providing the HA epitope sequences and Nathalie Gaudreault for performing the DNA sequencing analysis. GC is now at Laboratory of Chemical Carcinogenesis, National Institute for Cancer Research, Viale Benedetto XV, 10, I-16132 Genova, Italy.

\section{References}

Alnemri ES, Fernandes-Alnemri T and Litwack G (1995) Cloning and expression of four novel isoforms of human interleukin-1 beta converting enzyme with different apoptotic activities. Journal of Biological Chemistry 270: 4313-4317

Apte SS, Mattei MG and Olsen BR (1995) Mapping of the Human Bax gene to chromosome 19q13.3-q13.4 and isolation of a novel alternatively spliced transcript, Bax $\delta$. Genomics 26: 529-594

Bargou RC, Daniel PT, Mapara MY, Bommert K, Wagener C, Kallinich B, Royer HD and Dorken B (1995) Expression of the bcl-2 gene family in normal and malignan breast tissue: low bax-alpha expression in tumor cells correlates with resistance towards apoptosis. International Journal of Cancer 60: 854-859

Barry MA, Behnke CA and Eastman A (1990) Activation of programmed cell death (apoptosis) by cisplatin, other anticancer drugs, toxins and hypothermia. Biochem. Pharmacol. 40: 2353-2362
Bertrand R, Kohn K, Solary E and Pommier Y (1995) Detection of apoptosisassociated DNA fragmentation using a rapid and quantitative filter elution assay. Drug Development Res. 34: 138-144

Bertrand R, O'Connor P, Kerrigan D and PommierY (1992) Sequential administration of camptothecin and etoposide circumvents the antagnostic cytotoxicity of simultaneous drug administration in slowly growing human carcinoma, HT-29 cells. Eur. J. Cancer 28A: 743-748

Bertrand R and Pommier Y (1995) Assessment of DNA damage in Mammalian cells by DNA filter elution methodology. In GP Studzinski (Ed.), Cell growth and apoptosis; A practical approach, (Vol. 159, pp. 97-118). New York: IRL Press

Bertrand R, Sarang M, Jenkin J, Kerrigan D and Pommier Y (1991) Differential induction of secondary DNA fragmentation by topoisomerase II inhibitors in human tumor cell lines with amplified c-myc expression. Cancer Research 51: 6280-6285

Bertrand R, Solary E, Jenkins J and Pommier Y (1993) Apoptosis and its modulation in human promyelocytic HL-60 cells treated with DNA topoisomerase I and II inhibitors. Experimental Cell Research 207: 388-397

Boise LH, Gonzalez-Garcia M, Postema CE, Ding L, Lindsten T, Turka LA, Mao X, Nunez $G$ and Thompson CB (1993) bcl-x, a bcl-2-related gene that functions as a dominant regulator of apoptotic cell death. Cell 74: 597-608

Boldin MP, Goncharov TM, Goltsev YV and Wallach D (1996) Involvement of mach, a novel mort1/fadd-interacting protease, in fas/Apo-1- and Tnf receptor-induced cell death. Cell 85: 803-815

Boyd JM, Gallo GJ, Elangovan B, Houghton AB, Malstrom S, Avery BJ, Ebb RG, Subramanian T, Chittenden T, Lutz RJ and Chinnadurai G (1995) Bik, a novel death-inducing protein shares a distinct sequence motif with $\mathrm{Bcl}-2$ family proteins and interacts with viral and cellular survival-promoting proteins. Oncogene 11: $1921-1928$

Chittenden T, Harrington EA, O'Connor R, Flemington C, Lutz RJ, Evan GI and Guild BC (1995) Induction of apoptosis by the Bcl-2 homologue Bak. Nature 374: 733736

Choi SS, Park IC, Yun JW, Sung YC, Hong SI and Shin HS (1995) A novel Bcl-2 related gene, Bfl-1, is overexpressed in stomach cancer and preferentially expressed in bone marrow. Oncogene 11: 1693-1698

Chresta CM, Masters JRW and Hickman JA (1996) Hypersensitivity of human testicular tumors to etoposide-induced apoptosis is associated with functional p53 and a high Bax-Bcl-2 ratio. Cancer Research 56: 1834-1841

Clarke ML, Smith SD and Sklar J (1986) Cloning and structural analysis of cDNAs for $\mathrm{bcl}-2$ and a hybrid bcl-2/immunoglobulin transcript resulting from the $t(14 ; 18)$ translocation. Cell 47: 19-28

Das R, Reddy EP, Chatterjee D and Andrews DW (1996) Identification of a novelBcl-2 related gene, Brag-1, in human glioma. Oncogene 12: 947-951

Datta R, Manome Y, Taneja N, Boise L, Weichselbaum R, Thompson C and Kufe D (1995) Overexpression of $\mathrm{Bcl}-\mathrm{xL}$ by cytotoxic drug exposure confers resistance to ionizing radiation-induced internucleosomal DNA fragmentation. Cell Growth and Differentiation 6: 363-370

DelBino G, Bruno S, YiPN and Darzynkiewicz Z (1992) Apoptotic cell death triggered by camptothecin or teniposide. The cell cycle specificity and effects of ionizing radiation. Cell Proliferation 25: $537-548$

Deveraux QL, Takahashi R, Salvesen GS and Reed JC (1997) X-linked iap is a direct inhibitor of cell-death proteases. Nature 388: 300-304

Dole MG, Jasty R, Cooper MJ, Thompson CB, Nunez G and Castle VP (1995) Bcl$X(L)$ is expressed in neuroblastoma cells and modulates chemotherapy-induced apoptosis. Cancer Research 55: 2576-2582

Duan HJ, Chinnaiyan AM, Hudson PL, Wing JP, HeWW and Dixit V (1996a) Ice-Lap3, a novel mammalian homologue of the caenorhabditis elegans cell death protein Ced-3 is activated during Fas- and tumor necrosis factor-induced apoptosis. Journal of Biological Chemistry 271: 1621-1625

Duan HJ, Orth K, Chinnaiyan AM, Poirier GG, Froelich CJ, HeWW and Dixit V (1996b) Ice-Lap3, a novel member of the Ice/Ced-3 gene family, is activated by the cytotoxic T cell protease granzyme B. Journal of Biological Chemistry 271: $16720-16724$

Ealovega MW, McGinnis PK, Sumantran VN, Clarke MF and Wicha MS (1996) Bcl$X(S)$ gene therapy induces apoptosis of human mammary tumors in nude mice. Cancer Research 56: 1965-1969

Fang W, Rivard JJ, Ganser JA, Lebien TW, Nath KA, Mueller DL and Behrens TW (1995) Bcl-X(L) rescues Wehi $231 \mathrm{~B}$ lymphocytes from oxidant-mediated death following diverse apoptotic stimuli. Journal of Immunology 155: 66-75 
Farrow SN, White JH, Martinou I, Raven T, Pun KT, Grinham CJ, Martinou JC and Brown R (1995) Cloning of a bcl-2 homologue by interaction with adenovirus E1B 19K. Nature 374: 731-733

Faucheu C, Blanchet AM, Collarddutilleul V, Lalanne JL and Diuhercend A (1996) Identification of a cysteine protease closely related to interleukin-1-betaconverting enzyme. European Journal of Biochemistry 236: 207-213

Faucheu C, Diu A, Chan AW, Blanchet AM, Miossec C, Herve F, Collard-Dutilleul V, Gu Y, Aldape RA, Lippke JA et al (1995) A novel human protease similar to the interleukin-1 beta converting enzyme induces apoptosis in transfected cells. EMBO Journal 14: 1914-1922

Fernandes-Alnemri T, Amstrong RC, Krebs J, Srinivasula SM, Wang L, Bullrich F, Fritz LC, Trapani JA, Tomaselli KJ, Litwack G and Alnemri ES (1996) In vitro activation of CPP32 and Mch3 by Mch4, a novel human apoptotic cysteine protease containing two FDD-like domains. Proc. Natl. Acad. Sci. USA 93: $7464-7469$

Fernandes-Alnemri T, Litwack G and Alnemri ES (1994) CPP32, a novel human apoptotic protein with homology to Caenorhabditis elegans cell death protein Ced-3 and mammalian interleukin-1 beta-converting enzyme. Journal of Biological Chemistry 269: 30761-30764

Fernandes-Alnemri T, Litwack G and Alnemri E (1995) Mch2, a new member of the apoptotic Ced-3/lce cysteine protease gene family. Cancer Research 55: 2737 2742

Fernandes-Alnemri T, Takahashi A, Armstrong R, Krebs J, Fritz L, Tomaselli KJ, Wang L, Yu Z, Croce CM, Salveson G, Earnshaw WC, Litwack G and Alnemri ES (1995) Mch3, anovel human apoptotic cysteine protease highly related to Cpp32. Cancer Research 5: 6045-6052

Gibson L, Holmgreen SP, Huang DCS, Bernand O, Copeland NG, Jenkins NA, Sutherland GR, BakerE, Adams JM and Cory S (1996) Bcl-W, a novel member of the Bcl-2 family, promotes cell survival. Oncogene 13: $665-675$

Gupta M, Fujimori A and Pommier Y (1995) Eukaryotic DNA topoisomerase I. Biochim. Biophysi. Acta 1262: 1-14

Hickman JA (1996) Apoptosis and chemotherapy resistance. European Journal of Cancer 32A: 921-926

Hirsch T, Marchetti P, Susin SA, Dallaporta B, Zamzami N, Marzo I, Geuskens M and Kroemer G (1997) The apoptosis-necrosis paradox - apoptogenic proteases activated after mitochondrial permeability transition determine the mode of cell death. Oncogene 15: 1573-1581

Hockenbery D, Nunez G, Milliman C, Schreiber RD and Korsmeyer SJ (1990) Bcl-2 is an inner mitochondrial membrane protein that blocks programmed cell death. Nature 348: $334-336$

Hockenbery DM (1995) BCL-2, a novel regulator of cell death. Bioessays 17: 631 638

Horner D, Lewis M and Farrell PJ (1995) Novel hypotheses for the roles of EBNA-1 and BHRF1 in EBV-related cancers. Intervirology 38: 195-205

Ibrado AM, Huang Y, Fang GF and Bhalla K (1996) Bcl-X(L) overexpression inhibits taxol-induced yama protease activity and apoptosis. Cell Growth and Differentiation 7: 1087-1094

Jaxel C, Taudou G, Portemer C, Mirambeau G, Panijel J and Duguet M (1988) Topoisomerase inhibitors induce irreversible fragmentation of replicated DNA in concanavalin A stimulated splenocytes. Biochemistry 27: 95-99

Kamens J, Paskind M, Hugunin M, Talanian RV, Allen H, Banach D, Bump N, Hackett M, Johnston CG, Li P, Mankovich JA, Terranova M and Ghayur T (1995) Identification and characterization of Ich-2, a novel member of the interleukin-1beta-converting enzyme family of cysteine proteases. Journal of Biological Chemistry 270: $15250-15256$

Kaufmann SH (1989) Induction of endonucleolytic DNA cleavage in human acute myelogenous leukemia cells by etoposide, camptothecin, and other cytotoxic anticancer drugs: a cautionary note. Cancer Research 49: 5870-5878

Kiefer MC, BrauerMJ, Powers VC, WuJJ, Umansky SR, Tomei LD and BarrPJ (1995) Modulation of apoptosis by the widely distributed $\mathrm{Bcl}-2$ homologue Bak. Nature 374: $736-739$

Kitanaka C, Namiki T, Noguchi K, Mochizuki T, Kagaya S, Chi S, Hayashi A, Asai A Tsujimoto Y and Kuchino Y (1997) Caspase-dependent apoptosis of Cos-7 cells induced by Bax overexpression-differential effects of $\mathrm{Bcl}-2$ and $\mathrm{Bcl}-\mathrm{X}(\mathrm{L})$ on Baxinduced caspase activation and apoptosis. Oncogene 15: 1763-1772

Klein G and Dombos L (1973) Relationship between the sensitivity of EBV-carrying lymphoblastoid lines to superinfection and the inducibility of the resident viral genome. Int. J. Cancer 11: 327
Knudson CM, Tung KSK, TourtellotteWG, Brown GAJ and Korsmeyer SJ (1995) Baxdeficient mice with lymphoid hyperplasia and male germ cell death. Science 270: 96-99

Korsmeyer SJ (1992) Bcl-2 initiates a new category of oncogenes: Regulators of cell death. Blood 80: 879-886

Korsmeyer SJ (1995) Regulators of cell death. [Review]. Trends in Genetics 11: $101-105$

Kozopas KM, Yang T, Buchan HL, Zhou P and Craig RW (1995) MCL1. a gene expressed in programmed myeloid cell differentiation, has sequence similarity to Bcl-2. Proc. Natl. Acad. Sci. USA 90: 3516-3520

Krajewski S, Blomqvist C, Franssila K, Krajewska M, Wasenius VM, Niskanen E, Nordling S and Reed JC (1995) Reduced expression of proapoptotic gene BAX is associated with poor response rates to combination chemotherapy and shorter survival in women with metastatic breast adenocarcinoma. Cancer Research 55: $4471-4478$

Krajewski S, Krajewska M, Shabaik A, Miyashita T, Wang HG and Reed JC (1994) Immunohistochemical determination of In Vivo distribution of Bax, a dominant inhibitor of Bcl2. American Journal of Pathology 145: 1323-1336

Kumar S and Lavin MF (1996) The ICE family of cysteine proteases as effectors of cell death. Cell Death Differ. 3: 255-267

Lawrence JB, Villnave CA and Singer RH (1988) Sensitive, high-resolution chromatin and chromosome mapping in situ: presence and orientation of two closely integrated copies of EBV in a lymphoma cell line. Cell 52: 51-61

Lazebnik YA, Kaufmann SH, Desnoyers S, Poirier GG and Earnshaw WC (1994) Cleavage of poly(ADP-ribose) polymerase by a proteinase with properties like ICE. Nature 371: $346-347$

Lin EY, Orlofsky A, Berger MS and Prystowsky MB (1993) Characterization of A1, a novel hemopoietic-specific early-response gene with sequence similarity to bcl2. J. Immunol. 151: 1979-1988

Lippke JA, Gu Y, Sarnecke C, Caron PR and Su MSS (1996) Identification and characterization of Cpp32/2mch2 homolog 1, a novel cysteine protease similar to Cpp32. Journal of Biological Chemistry 271: 1825-1828

Luka J, Lindahl T and Klein G (1978) Purification of the Epstein-Barr virusdetermined nuclear antigen from Epstein-Barr virus-transformed human lymphoid cell lines. Journal of Virology 27: 604-611

Matsuo T, Heller M, Petti L, O'Shiro E and Kieff E (1984) Persistence of the entire Epstein-Barr virus genome integrated into human lymphocyte DNA. Science 226: $1322-1325$

McConkey DJ, Chandra J, WrightS, Plunkett W, McDonnell TJ, Reed JC and Keating M (1996) Apoptosis sensitivity in chronic lymphocytic leukemia is determined by endogenous endonuclease content and relative expression of $\mathrm{Bcl}-2$ and Bax. Journal of Immunology 156: 2624-2630

Miller SA, Dykes DD and Polesky HF (1988) A simple salting out procedure for extracting DNA from human nucleated cells. Nucleic Acids Res. 16: 1215

Miyashita T, Krajewski S, Krajewska M, Wang HG, Lin HK, Liebermann DA, Hoffman $B$ and Reed JC (1994) Tumor suppressor p53 is a regulator of bcl-2 and bax gene expression in vitro and in vivo. Oncogene 9: 1799-1805

Miyashita T and Reed JC (1995) Tumor suppressor p53 is a direct transcriptional activator of the human bax gene. Cell 80: 293-299

Monney L, Otter I, Olivier R, Ravn U, Mirzasaleh H, Fellay I, Poirier GG and Borner C (1996) Bcl-2 overexpression blocks activation of the death protease Cpp32/ Yama/Apopain. Biochemical \& Biophysical Research Communications 221: $340-345$

Munday NA, Vaillancourt JP, Ali A, Casano FJ, Miller DK, Molineaux SM, Yamin TT, Yu VL and Nicholson DW (1995) Molecular cloning and pro-apoptotic activity of ICErelll and ICErellII, members of the ICE/CED-3 family of cystein proteases. Journal of Biological Chemistry 270: 15870-15876

Muzio M, Chinnaiyan AM, Kischkel FC, Orourke K, Shevchenko A, Ni J, Scaffidi C, Bretz JD, Zhang M, Gentz R, Mann M, Krammer PH, Peter ME and Dixit VM (1996) Flice, a novel Fadd-homologous Ice/Ced-3-like protease, is recruited to the Cd95 (Fas/Apo-1) death-inducing signaling complex. Cell 85: 817-827

Nicholson DW, Ali A, Thornberry NA, Vaillancourt JP, Ding CK, Gallant M, Gareau Y, Griffin PR, Labelle M, Lazebnik YA et al (1995) Identification and inhibition of the ICE/CED-3 protease necessary for mammalian apoptosis. Nature 376: 37-43 O'Connor PM, Jackman J, Jondle D, Bhatia K, Magrath I and Kohn KW (1993) Role of the 53 tumor suppressor gene in cell cycle arrest and radiosensitivity of Burkitt's lymphoma cell lines. Cancer Research 53: 4776 - 4780 
Oltvai ZN and Korsmeyer SJ (1994) Checkpoints of dueling dimers foil death wishes. Cell 79: 189-192

Oltvai ZN, Milliman CL and Korsmeyer SJ (1993) Bcl-2 heterodimerizes in vivo with a conserved homolog, Bax, that accelerates programmed cell death. Cell 74 : $609-619$

Patel T, Gores GJ and Kaufmann SH (1996) The role of proteases during apoptosis. FASEB Journal 10: 587-597

Pearson GR, Luka J, Petti L, Sample J, Birkenbach M, Braun D and Kieff E (1987) Identification of an Epstein-Barr virus early gene encoding a second component of the restricted early antigen complex. Virology 160: 151-161

Pommier Y (1997) DNA topoisomerase II inhibitors. In BA Teicher (Ed.), Cancer Therapeutics: Experimental and Clinical Agents, (pp. 153-174). Totowa, New Jersey: Humana Press Inc

Raff MC, Barres BA, Burne JF, Coles HS, Ishizaki Y and Jacobson MD (1994) Programmed cell death and the control of cell survival. Philosophical Transactions of the Royal Society of London - Series B. Biological Sciences 345: $265-268$

Reed JC (1995) Bcl-2 family proteins - regulators of chemoresistance in cancer. Toxicology Letters 3: $155-158$

Reed JC (1997) Double identity for proteins of the Bcl-2 family. Nature 387: 773-776

Sakakura C, Sweeney EA, Shirahama T, Igarashi Y, Hakomori S, Nakatani $\mathrm{H}$ Tsujimoto H, Imanishi T, Ohgaki M, Ohyama T, Yamazaki J, Hagiwara A, Yamaguchi T, Sawai K and Takahashi T (1996) Overexpression of Bax sensitizes human breast cancer Mcf-7 cells to radiation-induced apoptosis. International Journal of Cancer 67: 101-105

Sakakura C, Sweeney EA, Shirahama T, Igarashi Y, Hakomori S, Tsujimoto H, Imanishi T, Ogaki M, Ohyama T, Yamazaki J, Hagiwara A, Yamaguchi T, SawaiK and Takahashi T (1997) Overexpression of Bax sensitizes breast cancer Mcf-7 cells to cisplatin and etoposide. Surgery Today 27: 676-679

Sample J, Liebowitz D and Kieff E (1989) Two related Epstein - Barr virus membrane proteins are encoded by separate genes. Journal of Virology 63: 933-937

Sané AT, Schmitt E, Steyaert A, Meyer D and Bertrand R (1997) The CrmA- and TPCK-sensitive pathways that trigger the oligonucleosome-sized DNA fragmentation in camptothecin-induced apoptosis: relation to caspase activation and hig molecular weight DNA fragmentation. Biochemical and Cellular Biology 75: 359-368

Sawada K, Yamamoto M, Tabata T, Smith M, Tanaka A and Nonoyama M (1989) Expression of EBNA-3 family in fresh B lymphocytes infected with Epstein-Barr virus. Virology 168: 22-30

Sedlak TW, Oltvai ZN, Yang E, Wang K, Boise LH, Thompson CB and Korsmeyer SJ (1995) Multiple Bcl-2 family members demonstrate selective dimerizations with Bax. Proc. Natl. Acad. Sci. USA 92: 7834-7838

Shimizu S, Eguchi Y, KamiikeW, Matsuda Hand Tsujimoto Y (1996)Bcl-2 expression prevents activation of the ice protease cascade. Oncogene 12: 2251-2257

Simonian PL, Grillot DAM, Merino R and Nunez G (1996) Bax can antagonize Bcl$X(L)$ during etoposide and cisplatin-induced cell death independently of its heterodimerization with Bcl-X(L). Journal of Biological Chemistry 271: 2276422772

Solary E, Bertrand R, Kohn KW and Pommier Y (1993) Differential induction of apoptosis in undifferentiated and differentiated HL-60 cells by DNA topoisomerase I and II inhibitors. Blood 81: 1359-1368

Strobel T, Swanson L, Korsmeyer S and Cannistra SA (1996) Bax enhances paclitaxel-induced apoptosis through a p53-independent pathway. Proc. Natl. Acad. Sci. USA 93: 14094-14099

Sumantran VN, Ealovega MW, Nunez G, Clarke MF and Wicha MS (1995) Overexpression of $\mathrm{Bcl}-\mathrm{X}(\mathrm{S})$, sensitizes Mcf-7 cells to chemotherapy-induced apoptosis. Cancer Research 55: 2507-2510
Takayama S, Kochel K, Irie S, Inazawa J, Abe J, Sato T, Druck T, HuebnerK Kand Reed JC (1996) Cloning of Cdnas encoding the human Bag 1 protein and localization of the human Bag1 gene to chromosome 9p12. Genomics 35: 494-498

Takayama S, Sato T, Krajewski S, Kochel K, Irie S, Millan JA and JC R (1995) Cloning and functional analysis of Bag-1; a novel $\mathrm{Bcl}-2$ binding protein with anti-cell death activity. Cell 80: 279-284

Tewari M, Quan LT, Orourke K, Desnoyers S, Zeng Z, Beidler DR, Poirier GG, Salvesen GS and Dixit VM (1995) Yama/Cpp32-Beta, a mammalian homolog of Ced-3, is a Crma-inhibitable protease that cleaves the death substrate Poly(ADP-ribose) polymerase. Cell 81: 801-809

Thomas A, Elrouby S, Reed JC, Krajewski S, Silber R, Potmesil M and Newcomb EW (1996) Drug-induced apoptosis in B-cell chronic lymphocytic leukemia relationship between p53 gene mutation and $\mathrm{Bcl}-2 / \mathrm{Bax}$ proteins in drug resistance. Oncogene 12: 1055-1062

Thompson CB (1995) Apoptosis in the pathogenesis and treatment of disease. Science 267: 1456-1462

Tsujiimoto Y, Finger LR, Yunis J, Nowell PC and Croce CM (1984) Cloning of the chromosome breakpoint of neoplastic $B$ cells with the $t(14: 18)$ chromosome translocation. Science 226: 1097-1099

Vaux DL, Cory S and Adams JM (1988) Bcl-2 gene promotes haemopoietic cell survival and cooperates with c-myc to immortalize pre-B cells. Nature 355: 440 442

Wagener C, Bargou RC, Daniel PT, Bommert K, Mapara MY, Royer HD and Dorken B (1996) Induction of the death-promoting gene Bax-alpha sensitizes cultured breast cancer cells to drug-induced apoptosis. International Journal of Cancer 67: $138-141$

Walker PR, Smith C, Youdale T, Leblanc J, Whitfield JF and Sikorska M (1991) Topoisomerase II-reactive chemotherapeutic drugs induce apoptosis in thymocytes. Cancer Research 51: 1078-1085

Wang L, Miura M, Bergeron L, Zhu H and Yuan J (1994) Ich-1, an Ice/ced-3-related gene, encodes both positive and negative regulators of programmed cell death. Cell 78: 739-750

Wang K, Yin XM, Chao DT, Milliman CL and Korsmeyer SJ (1996) Bid - a novel Bh3 domain-only agonist. Genes \& Development 10: 2859-2869

Wang SY, Miura M, Jung YK, Zhu H, Gagliardini V, Shi LF, Greenberg AH and Yuan JY (1996) Identification and characterization of Ich-3, a member of the interleukin-1-beta converting enzyme (Ice)/Ced-3 family and an upstream regulator of Ice. Journal of Biological Chemistry 271: 20580-20587

Wyllie AH (1997) Apoptosis and carcinogenesis. European Journal of Cell Biology 73: $189-197$

Xerri L, Parc P, Brousset P, Schlaifer D, Hassoun J, Reed JC, Krajewski S and Birnbaum D (1996) Predominant expression of the long isoform of Bcl-X (Bcl-XI) in human lymphomas. British Journal of Haematology 92: 900-906

Xiang JL, Chao DT and Korsmeyer SJ (1996) Bax-induced cell death may not require interleukin 1-beta-converting enzyme-like proteases. Proc. Natl. Acad. Sci. USA 93: $14559-14563$

Yang E, Zha J, Jockel J, Boise LH, Thompson CB and Korsmeyer SJ (1995) Bad, a heterodimeric partner for $\mathrm{Bcl}-\mathrm{XL}$ and $\mathrm{Bcl}-2$, displaces $\mathrm{Bax}$ and promotes cell death. Cell 80: 285-291

Yuan J, Shaham S, Ledoux S, Ellis HM, Horvitz R (1993) The C. elegans cell death gene ced-3 encodes a protein similar to mammalian interleukine-1B-converting enzyme. Cell 75: 641-652 